\title{
Peat decomposition records in three pristine ombrotrophic bogs in southern Patagonia
}

\author{
T. Broder ${ }^{1}$, C. Blodau ${ }^{2, *}$, H. Biester ${ }^{3}$, and K. H. Knorr ${ }^{1}$ \\ ${ }^{1}$ Limnological Research Station and Department of Hydrology, University of Bayreuth, Germany \\ ${ }^{2}$ School of Environmental Sciences, University of Guelph, Canada \\ ${ }^{3}$ Institute for Geoecology, TU-Braunschweig, Germany \\ * present address: Hydrology Group, Institute of Landscape Ecology, FB 14 Geosciences, University of Münster, Germany
}

Correspondence to: K. H. Knorr (kh.knorr@uni-bayreuth.de)

Received: 16 September 2011 - Published in Biogeosciences Discuss.: 26 October 2011

Revised: 14 March 2012 - Accepted: 3 April 2012 - Published: 20 April 2012

\begin{abstract}
Ombrotrophic bogs in southern Patagonia have been examined with regard to paleoclimatic and geochemical research questions but knowledge about organic matter decomposition in these bogs is limited. Therefore, we examined peat humification with depth by Fourier Transformed Infrared (FTIR) measurements of solid peat, $\mathrm{C} / \mathrm{N}$ ratio, and $\delta^{13} \mathrm{C}$ and $\delta^{15} \mathrm{~N}$ isotope measurements in three bog sites. Peat decomposition generally increased with depth but distinct small scale variation occurred, reflecting fluctuations in factors controlling decomposition. $\mathrm{C} / \mathrm{N}$ ratios varied mostly between 40 and 120 and were significantly correlated $\left(R^{2}>0.55, p<0.01\right)$ with FTIR-derived humification indices. The degree of decomposition was lowest at a site presently dominated by Sphagnum mosses. The peat was most strongly decomposed at the driest site, where currently peat-forming vegetation produced less refractory organic material, possibly due to fertilizing effects of high sea spray deposition. Decomposition of peat was also advanced near ash layers, suggesting a stimulation of decomposition by ash deposition. Values of $\delta^{13} \mathrm{C}$ were $26.5 \pm 2 \%$ in the peat and partly related to decomposition indices, while $\delta^{15} \mathrm{~N}$ in the peat varied around zero and did not consistently relate to any decomposition index. Concentrations of DOM partly related to $\mathrm{C} / \mathrm{N}$ ratios, partly to FTIR derived indices. They were not conclusively linked to the decomposition degree of the peat. DOM was enriched in ${ }^{13} \mathrm{C}$ and in ${ }^{15} \mathrm{~N}$ relative to the solid phase probably due to multiple microbial modifications and recycling of $\mathrm{N}$ in these $\mathrm{N}$-poor environments. In summary, the depth profiles of $\mathrm{C} / \mathrm{N}$ ratios, $\delta^{13} \mathrm{C}$ values, and FTIR spectra seemed to reflect changes in environmen-
\end{abstract}

tal conditions affecting decomposition, such as bog wetness, but were dominated by site specific factors, and are further influenced by ash deposition and possibly by sea spray input.

\section{Introduction}

Peatlands cover about $3 \%$ of the earth's surface (Aselmann and Crutzen, 1989) and occur in three different regions: a northern (boreal), tropical and southern region. Southern peatlands, mostly in Patagonia, have accumulated 13 to $18 \mathrm{Pg} \mathrm{C}$ during the Holocene with an overall accumulation rate of $22 \mathrm{~g} \mathrm{C} \mathrm{m}^{-2} \mathrm{yr}^{-1}$ and cover $45000 \mathrm{~km}^{2}$ (Yu et al., 2010). Prevailing westerly winds bring unpolluted air masses from the Pacific Ocean resulting in low atmospheric nitrogen deposition in the region (Godoy et al., 2003). As ombrotrophic bogs receive nutrients by atmospheric depositions only, Patagonian bogs provide a reference system compared to more polluted northern bogs. Southern Patagonia peatlands have thus been frequently used as paleoclimate archives (e.g. McCulloch and Davies, 2001; Markgraf, 1993; Heusser et al., 2000) and for examination of halogen and mercury deposition records (Biester et al., 2003, 2004). The validity of such records partly depends on the decomposition patterns of organic matter but investigations of different, complementary proxies to address this issue are scarce for this region.

In temperate bogs the majority of organic matter is decomposed in the upper, unsaturated layer of peat, i.e. the acrotelm, and only $10-20 \%$ of the litter mass reaches the 
underlying, water-saturated catotelm. Here, anaerobic decomposition proceeds at a rate of only $\sim 1 \%$ or less of the rate in the acrotelm (Clymo, 1984; Frolking et al., 2001; Beer et al., 2008). Controls on decomposition rates are the plant community type (e.g. Bragazza et al., 2007), temperature (e.g. Bridgham et al., 1999) and waterlevel position and soil moisture (e.g. Laiho, 2006). The slow decomposition rates under permanently waterlogged conditions result from combined effects of limited oxygen diffusion into the saturated peat, the poorly decomposable litter of Sphagnum vegetation (e.g. Hogg, 1993), low temperatures and further constraints on the processes, such as enzymatic activities or free energy limitations (e.g. Freeman et al., 2001; Beer and Blodau, 2007).

Due to strong westerly winds and their close proximity to the sea peatlands in southern Patagonia are exposed to sea spray, which was shown to influence vegetation due to a fertilizing effect (Kleinebecker et al., 2008). As the containing sulfate may be used as an electron acceptor for anaerobic respiration (Segers and Kengen, 1998) also a stimulation of anaerobic respiration and thus decomposition by sea spray input may be postulated. Retained halogens in the peat thereby serve as an indicator for the extent of sea spray input (Biester et al., 2004). In Patagonia also ash layers from various volcanic eruptions in the past occur, which can have an additional stimulating effect on decomposition due to nutrient supply or release of electron acceptors, such as sulfate, during weathering and diagenesis of the ashes (Hotes et al., 2010).

While such potential influences on organic matter decomposition and humification patterns have been identified, their relative impact is unknown. In this study we attempted to address this research gap using several indicators of organic matter decomposition along the depositional record, i.e. $\mathrm{C} / \mathrm{N}$ ratios of organic matter, Fourier Transform Infrared spectroscopy (FTIR) and content of stable ${ }^{13} \mathrm{C}$ and ${ }^{15} \mathrm{~N}$ isotopes in the peat. $\mathrm{C} / \mathrm{N}$ ratios of the organic material have been shown to relate to decomposition processes (e.g. Malmer and Holm, 1984) as microbial consumption of carbon- and hydrogen-rich organic substances results in a decreased abundance of carbon relative to nitrogen. Relative nitrogen abundance increased during decomposition because mineralized nitrogen is mostly retained in microbial biomass (Damman, 1988). Therefore, the $\mathrm{C} / \mathrm{N}$ ratio has been commonly used as indicator for the degree of decomposition, based on the relatively higher loss of $\mathrm{C}$ compared to $\mathrm{N}$ during decomposition and thus indicating peat mass loss (e.g. Hornibrook et al., 2000; Kuhry and Vitt, 1996). Fourier Transform Infrared spectroscopy (FTIR) has been widely used to characterize organic matter quality of humic and fulvic acids and bulk peat (e.g. Holmgren and Norden, 1988; Niemeyer et al., 1992) and provides information about the relative abundance of functional groups. This method is thus used to identify humification processes, i.e. changes in the molecular structure of organic matter, based on an increase in the relative abun- dance of recalcitrant moieties such as aliphatics or aromatics compared to labile fractions, such as carbohydrates (e.g. Beer et al., 2008; Kalbitz et al., 1999; Cocozza et al., 2003). More decomposed peat was further reported to release less DOC than undecomposed peat (Biester et al., 2006; Kalbitz and Geyer, 2002). Thus, an inverse relation of the peat degree of decomposition and DOC concentrations may be expected, although the DOC quality and thus degradability may also change. Isotope ratios have been quantified as well as an indicator of decomposition processes, as changes were assumed to reflect isotope fractionation by microbial processes because of preferential utilization of ${ }^{12} \mathrm{C}$ (e.g. Kalbitz and Geyer, 2002; Novak et al., 1999). This interpretation is in line with Hornibrook et al.'s (2000) finding that $\mathrm{C} / \mathrm{N}$ and $\delta^{13} \mathrm{C}$ values in peat soils correlated. As changing vegetation, microhabitat or climate also affect $\delta^{13} \mathrm{C}$ values, their interpretation with respect to decomposition or paleoclimatic conditions needs caution (Pancost et al., 2003; Price et al., 1997; Novak et al., 2010; Skrzypek et al., 2007). Other than $\delta^{13} \mathrm{C}$, also $\delta^{15} \mathrm{~N}$ has been applied to track nitrogen transformation during decomposition in organic soils (Kalbitz et al., 2000).

The aim of this study was thus to elucidate organic matter decomposition patterns in Patagonian ombrotrophic bogs using a set of complementary decomposition indices as outlined above. We assumed decomposition to be mainly controlled by water table levels and temperature and considered potential nutrient and electron acceptor inputs through sea spray and ash deposition as additional factors. We expected advanced decomposition (i) under drier conditions and (ii) with increasing inputs from sea spray and ash deposition.

\section{Materials and methods}

\subsection{Site description}

The investigated bogs (SkyI, SkyII, PBr2) are located in southern Patagonia near Punta Arenas (Chile) (Fig. 1) and have been partly described by Biester et al. (2003). They are situated between the Magellanic Moorlands with up to $10000 \mathrm{~mm} \mathrm{yr}^{-1}$ and the Pampa grassland with less than $500 \mathrm{~mm} \mathrm{yr}^{-1}$ of precipitation. Mean annual temperature is about $6.5^{\circ} \mathrm{C}$ (Schneider et al., 2003). We derived relative differences in spray input by mean bromide concentrations in the solid peat, as bromide is a major constituent of sea spray and better retained in the peat than chloride (Biester et al., 2006). Highest precipitation occurs at the SkyI site $\left(\sim 1500 \mathrm{~mm} \mathrm{yr}^{-1}\right)$. The vegetation of the central raised part is dominated by Sphagnum mosses (e.g. Sphagnum magellanicum), shrubs (e.g. Empetrum rubrum) and cushion plants (e.g. Astelia pumila) and reaches a peat thickness of $3 \mathrm{~m}$ (Biester et al., 2003; Kilian et al., 2003). Precipitation at the SkyII site is less, about $1000 \mathrm{~mm} \mathrm{yr}^{-1}$, as measured in close vicinity (Schneider et al., 2003). Cushion plants are absent, 


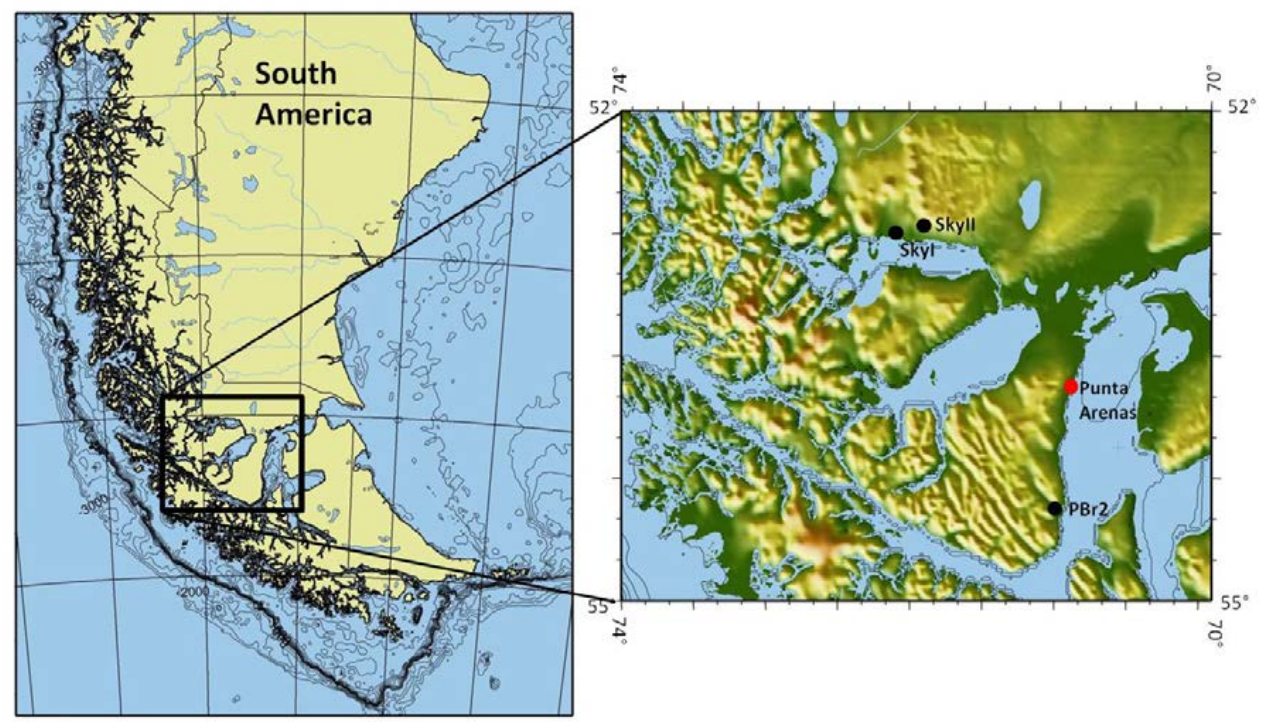

Fig. 1. Map of the study area in southern South America. Locations of the sampling sites are marked in the detailed map. Maps were generated online at https://sfb574.ifm-geomar.de/gmt-maps at 26 February 2011 (IFM-GEOMAR).

dominating species are Sphagnum magellanicum and Empetrum rubrum and hummock-hollow micro-topography is pronounced. Peat thickness reaches $>4 \mathrm{~m}$ in the central part (I. Reisen, personal communication, 2011). The third site, $\mathrm{PBr} 2$, receives the least precipitation of $650-800 \mathrm{~mm} \mathrm{yr}^{-1}$ (Heusser et al., 2000). The vegetation is dominated by Empetrum rubrum, Sphagnum magellanicum, sedges and rushes. Mean peat thickness is about $6.50 \mathrm{~m}$ (Kilian et al., 2003). At the SkyI and $\mathrm{PBr} 2$ sites, tephra layers from eruptions of volcanoes located in the southern Andes had previously been described (Kilian et al., 2003). All bogs are underlain by acidic and base-poor materials (Kleinebecker et al., 2008).

\subsection{Field sampling}

Field sampling was conducted in March/April 2010 in hollows. The water level was determined using piezometers (PVC) of $4 \mathrm{~cm}$ diameter, fully slotted and $1 \mathrm{~m}$ in depth. Hydraulic conductivity $\left(k_{\mathrm{H}}\right)$ was obtained using piezometers (PVC) of similar design and a slotted segment of $20 \mathrm{~cm}$ in 1,2 or $3 \mathrm{~m}$ depth. Values of $k_{\mathrm{H}}$ in the catotelm were determined in slug tests on several occasions using a temperature and air pressure compensated water pressure transducer over several days with a temporal resolution of $1 \mathrm{~min}$ (Levelogger Gold and Barologger, Solinst, Georgetown, Canada), following the Hvorslev method as described in Fetter (2001). This method has been successfully applied in peatland environments (e.g. Chason and Siegel, 1986; Fraser et al., 2001; Baird et al., 2008).

Peat samples were collected using a Russian peat corer (Eijkelkamp Agrisearch Equipment BV, Giesbeek, Nether- lands). Cores were extracted to a depth of $300 \mathrm{~cm}$ in the SkyII and $\mathrm{PBr} 2$ bog and $180 \mathrm{~cm}$ in SkyI bog, divided into $10 \mathrm{~cm}$ segments and filled in plastic bags (Whirl Paks ${ }^{\circledR}$, Nasco, Fort Atkinson, USA). Distinct volcanic ash layers were sampled separately. Samples were stored at $\sim 5^{\circ} \mathrm{C}$ until freeze drying. Visible plant roots were removed before milling in the laboratory. Vegetation samples for isotope measurements and carbon and nitrogen contents were collected at the SkyI bog.

To extract greater volumes of pore-water samples for isotope measurements on DOM, we applied a pore-water suction sampler consisting of PE-sinter pieces $(5 \times 0.5 \times 1 \mathrm{~cm})$ inserted in a $3.50 \mathrm{~m}$ long rod at different depths and connected by tubing $(2.5 \times 4 \mathrm{~mm}$, Polyurethane) to a stop-cock above the peatland surface. Suction samplers were installed at least one day prior to sampling and samples taken over a maximum period of two days by standard PE syringes, discarding the first milliliters of sampled water. The suction technique had a resolution of $20 \mathrm{~cm}$ to a max. depth of $195 \mathrm{~cm}$ and a $30 \mathrm{~cm}$ resolution beyond to max. $345 \mathrm{~cm}$. Samples were transferred in $125 \mathrm{ml}$ PE-flasks (Nalgene), stored at $\sim 5^{\circ} \mathrm{C}$ and analyzed within $12-14$ days.

\subsection{Analytical procedures}

For solid phase characterization, FTIR-spectra of the ground peat samples were obtained using a Vector 22 FTIR spectrometer (Bruker Optik, Ettlingen, Germany; absorption mode, subsequent baseline subtraction) on $\mathrm{KBr}$ pellets (200 mg dried $\mathrm{KBr}$ and $2 \mathrm{mg}$ sample). Measurements were recorded from 4500 to $300 \mathrm{~cm}^{-1}$ using a resolution of $2 \mathrm{~cm}^{-1}$. A number of 32 scans per sample were averaged. Focusing on the absorption range containing most relevant 
Table 1. Overview of calculated FTIR ratios as a humification index according to Beer et al. (2008) and attribution of structural units in organic matter FTIR-spectra after Niemeyer et al. (1992) and Senesi et al. (1989).

\begin{tabular}{ll}
\hline Ratio & Indicative for \\
\hline $1720 / 1090$ & carbonylic and carboxylic $\mathrm{C}=\mathrm{O}$ (carboxylic acids and aromatic esters)/polysaccharides \\
$1630 / 1090$ & Aromatic $\mathrm{C}=\mathrm{C}$ and $\mathrm{COO}^{-}$(aromatics and aromatic or aliphatic carboxilates)/polysaccharides \\
$1510 / 1090$ & Aromatic $\mathrm{C}=\mathrm{C}$ or $\mathrm{C}=\mathrm{O}$ of amides/polysaccharides \\
$1420 / 1090$ & $\mathrm{OH}$ and $\mathrm{CO}$ of phenols or $\mathrm{CH}$ of $\mathrm{CH}_{2}$ and $\mathrm{CH}_{3}$ groups (phenolic and aliphatic structures)/polysaccharides \\
\hline
\end{tabular}

information (300-2000 $\left.\mathrm{cm}^{-1}\right)$, absorption peaks indicative of structural units in organic matter were used as an indicator for peat organic matter quality and identified according to Senesi et al. (1989) and Niemeyer et al. (1992) as follows: Absorption bands at $950-1170 \mathrm{~cm}^{-1}\left(\sim 1090 \mathrm{~cm}^{-1}\right)$ were allocated to $\mathrm{OH}$ vibrations of polysaccharides. Absorption at $\sim 1420 \mathrm{~cm}^{-1}$ was ascribed to $\mathrm{OH}$ deformations and $\mathrm{CO}$ stretch of phenols or $\mathrm{CH}$ deformation of $\mathrm{CH}_{2}$ or $\mathrm{CH}_{3}$ groups (phenolic and aliphatic structures), at $\sim 1510 \mathrm{~cm}^{-1}$ to aromatic $\mathrm{C}=\mathrm{C}$ or to $\mathrm{CO}$ of amide groups. The $\sim 1630 \mathrm{~cm}^{-1}$ region is indicative of aromatic $\mathrm{C}=\mathrm{C}$ and asymmetric $\mathrm{COO}^{-}$ group vibrations (lignin and other aromatics and aromatic or aliphatic carboxylates) and $\sim 1720 \mathrm{~cm}^{-1}$ of $\mathrm{CO}$ stretch of carbonyl and carboxyl groups (carboxylic acids and aromatic esters). To determine relative abundances of functional groups in form of a humification index, ratios between peak intensities for the following wavenumbers (given in $\mathrm{cm}^{-1}$ ) with respect to polysaccharides $\left(1090 \mathrm{~cm}^{-1}\right)$ were calculated: 1720/1090; 1630/1090; 1510/1090 and 1420/1090 (Holmgren and Norden, 1988; Niemeyer et al., 1992; Beer et al., 2008) (Table 1). These ratios are referred to as a humification index in the context of this paper, because humic substances are typically enriched in carboxylic, aromatic and phenolic moieties compared to polysaccharides (Norden et al., 1986).

For identification of volcanic ash layers, metal concentrations of the peat samples $(\mathrm{Rb}, \mathrm{Sr}$, and $\mathrm{Zr}$ ) were determined by an energy-dispersive miniprobe multielement analyzer (EMMA), which is a small desk-top X-ray Fluorescence analyzer (XRF) system. Absorption bands of minerals were identified after Marel and Beutelspacher (1976) in the FTIR-spectra and the affected samples were excluded from the interpretation of the FTIR-based humification indices. Furthermore, a set of samples was also examined with X-ray Diffraction (XRD; Siemens D5000, Co K $\alpha$ radiation; $2 \theta$ range $2^{\circ}$ to $80^{\circ}$ ) regarding mineral content.

Dissolved organic carbon (DOC) concentrations were quantified in $0.45 \mu \mathrm{m}$ filtered samples using a total carbon analyzer (Shimadzu TOC 5050). Pore-water samples for DOC and dissolved organic nitrogen (DON) isotope analysis were filtered, frozen in an ethanol bath $\left(-60^{\circ} \mathrm{C}\right)$ in round bottom flasks and subsequently freeze-dried.

Ratios of ${ }^{13} \mathrm{C} /{ }^{12} \mathrm{C}$ and ${ }^{15} \mathrm{~N} /{ }^{14} \mathrm{~N}$ and total carbon and nitrogen were quantified in freeze-dried bulk plant material, peat and DOM on mass basis using an elemental analyzer (CE instruments NA 1108, Milano, Italy), connected via ConFlo III interface to a delta S IR-MS (Thermo Finnigan MAT, Bremen, Germany). Isotope signatures are given in the common $\delta$-notation $\delta \% \circ=\left(\left(R_{\text {sample }} / R_{\text {standard }}\right)-1\right) \times 10^{3}$, relative to the V-PDB-standard or $\mathrm{N}_{2}$ in ambient air.

Statistical analyses were performed using PASW Statistics 18.0 (IBM Corporation). All data were tested for correlation with a level of significance $(p)$ of 0.01 and 0.05 (Pearson, two-tailed).

\section{Results}

\subsection{Water table and hydraulic conductivity}

The mean water table level over six weeks of the measurement period was $9 \pm 3 \mathrm{~cm}$ at the $\mathrm{PBr} 2$ site, $12 \pm 3 \mathrm{~cm}$ at the SkyI site, and $15 \pm 2 \mathrm{~cm}$ at the SkyII site (Table 2). Head recovery in the slug tests was s-shaped. The hydraulic conductivities reached $10^{-6} \mathrm{~m} \mathrm{~s}^{-1}$ in $1 \mathrm{~m}$ depth and $10^{-8} \mathrm{~m} \mathrm{~s}^{-1}$ in 2 and $3 \mathrm{~m}$ depth. At the $\mathrm{PBr} 2$ site hydraulic conductivity in $2 \mathrm{~m}$ depth was $10^{-6} \mathrm{~m} \mathrm{~s}^{-1}$ and thus higher than at the other sites.

\subsection{Identification of ash deposits and sea-spray input}

Several tephra layers were identified by elemental concentrations of Rubidium, Strontium and Zirconium (Fig. 2). Ash layers in the $\mathrm{PBr} 2$ record at around $175 \mathrm{~cm}$ and in the SkyII record at around $265 \mathrm{~cm}$ could be related to the Mt. Burney eruption $4250 \mathrm{yr}$ BP. In the SkyII record, two other layers in $125 \mathrm{~cm}$ and $200 \mathrm{~cm}$ depth were identified. Two small Rubidium peaks in $45 \mathrm{~cm}$ and $115 \mathrm{~cm}$ depth at the $\mathrm{PBr} 2$ record may also indicate ash layers. At the SkyI site, no tephra layers were evident from trace metal concentrations, except of two small peaks of Rubidium in $105 \mathrm{~cm}$ and Zirconium in $145 \mathrm{~cm}$ depth. At $180 \mathrm{~cm}$ depth, high metal concentrations indicated the influence of the underlying mineral rich sediment.

Following mean bromide concentrations in the solid peat, the SkyII bog received less sea spray (mean $\mathrm{Br}$ concentration of $48 \mathrm{mg} \mathrm{kg}^{-1}$ dry weight) than the other two bogs (SkyI: $86 \mathrm{mg} \mathrm{Br} \mathrm{kg}^{-1}$; PBr2: $97 \mathrm{mg} \mathrm{Br} \mathrm{kg}^{-1}$ ). 

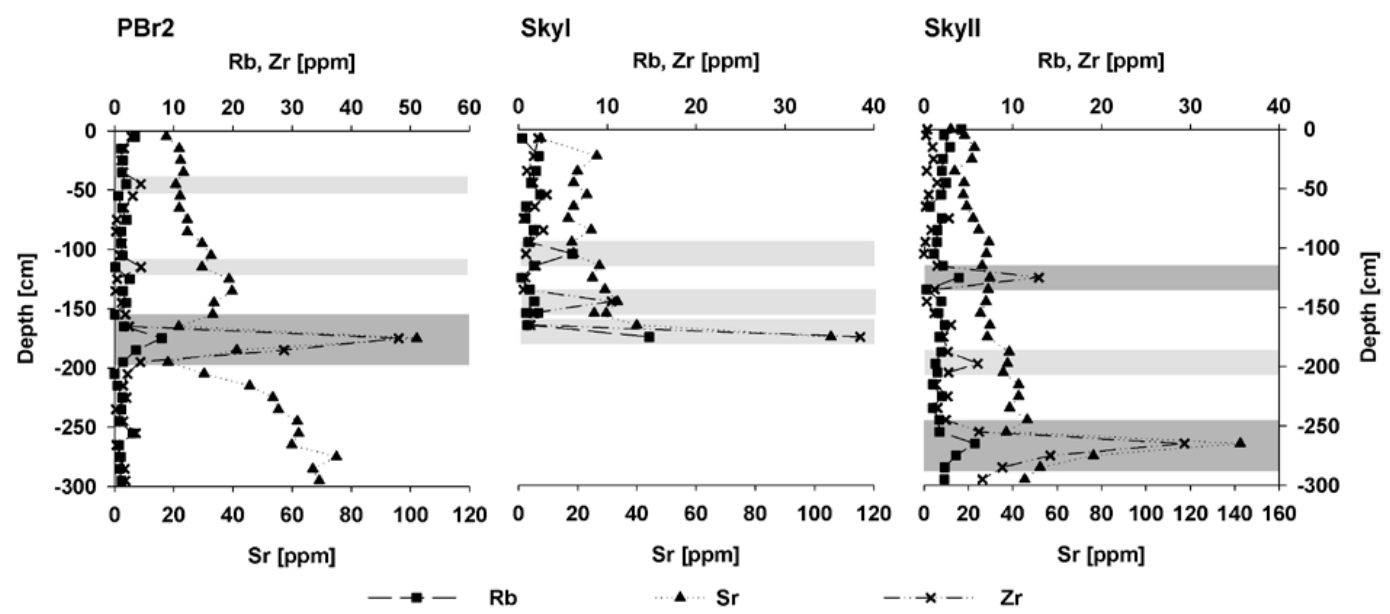

Fig. 2. Concentrations of Rubidium (solid squares), Strontium (solid triangles) and Zirconium (crosses) in the peat samples in parts per million. Clearly identified volcanic tephra layers are highlighted in gray. Less well defined tephra layers and underlying sediment in the SkyI record are highlighted by a lighter gray. The thick gray bands in the PBr2 and SkyII records indicate the deposit of the Mt. Burney eruption 4250 yr BP.

Table 2. Mean water table and hydraulic conductivity in 1,2 and $3 \mathrm{~m}$ depth at the three sites.

\begin{tabular}{lllll}
\hline Site & $\begin{array}{l}\text { Mean water level } \\
{[\mathrm{cm} \text { below surface }]}\end{array}$ & $\begin{array}{l}k_{\mathrm{H}}\left[\mathrm{m} \mathrm{s}^{-1}\right] \\
1 \mathrm{~m}\end{array}$ & $\begin{array}{l}k_{\mathrm{H}}\left[\mathrm{m} \mathrm{s}^{-1}\right] \\
2 \mathrm{~m}^{*}\end{array}$ & $\begin{array}{l}k_{\mathrm{H}}\left[\mathrm{m} \mathrm{s}^{-1}\right] \\
3 \mathrm{~m}^{*}\end{array}$ \\
\hline PBr2 & $9 \pm 3$ & $3.5 \times 10^{-6}$ & $1 \times 10^{-6}$ & $3 \times 10^{-8}$ \\
SkyI & $12 \pm 3$ & $1.5 \times 10^{-6}$ & $1.5 \times 10^{-8}$ & $1.5 \times 10^{-8}$ \\
SkyII & $15 \pm 2$ & $2.5 \times 10^{-6}$ & $3.5 \times 10^{-8}$ & $1 \times 10^{-8}$ \\
\hline
\end{tabular}

* In SkyI $2 \mathrm{~m}$ and $3 \mathrm{~m}$ Piezometer tubes were installed at the final depth of $1.80 \mathrm{~m}$.

\subsection{Spectroscopic characterization of organic matter quality and $\mathrm{C} / \mathrm{N}$ ratios as indicator for peat decom- position}

Comparing XRD and FTIR-spectra, we found an interference mainly of feldspar in the ash layer and in the deepest peat sample of the SkyI site (FTIR-spectra see Fig. 3). Feldspar bands in FTIR-spectra are found at $400-800 \mathrm{~nm}^{-1}$ and in the Polysaccharide region, thus FTIR results were not interpreted as humification index in case of any our methods indicated influence by ash derived minerals. All ratios (1720/1090, 1630/1090, 1510/1090 and 1420/1090) generally increased with depth, which meant a relative decrease of polysaccharides and a relative increase of aromatic, carboxylic, amid and phenolic moieties (see Table 1). As an example, the 1630/1090 ratio was correlated (Pearson) with depth with an $r$ of $0.508(\mathrm{PBr} 2)$ to 0.762 (SkyI) at the 0.01 level of significance (data not shown). Highest humification indices were observed at the $\mathrm{PBr} 2$ site. As the four FTIRratios given in Table 3 highly correlated with each other $(r>0.83, p<0.01)$, only the $1630 / 1090$ profile is shown in Fig. 4. Ratios of $\mathrm{C} / \mathrm{N}$ of the solid phase inversely correlated with calculated FTIR-ratios at a 0.01 level of significance using all data $(N=60$; see Table 3$)$. Correlation coefficients ranged from -0.310 ( $\mathrm{PBr} 2$, not significant) to -0.660 (SkyII, $p<0.01$ ), reaching -0.777 (SkyI, $p<0.01$ ) using data of the individual sites only (not shown) and distinct deviations from the inverse relationship were obvious e.g. at the SkyII site below $125 \mathrm{~cm}$ and at the $\mathrm{PBr} 2$ site below $175 \mathrm{~cm}$ (Fig. 4). Compared to FTIR humification indices, $\mathrm{C} / \mathrm{N}$ ratios were not correlated with depth, except of the record of SkyI.

In the $\mathrm{PBr} 2$ profile, the humification index was high, along with narrow $\mathrm{C} / \mathrm{N}$ ratios $(\sim 40)$ in the top $50 \mathrm{~cm}$, while the index declined to $0.7-0.9$ and $\mathrm{C} / \mathrm{N}$ increased below to $>80$. From $100 \mathrm{~cm}$ downward, this trend reversed and above the volcanic ash layer in $175 \mathrm{~cm}$ depth, the humification index peaked again $(\sim 1.3)$ along with narrow $\mathrm{C} / \mathrm{N}(50-55)$. In profiles of the SkyI and SkyII sites, the humification index was quite similar in the upper meter, but generally lower than in the $\mathrm{PBr} 2$ profile, and high $\mathrm{C} / \mathrm{N}$ ratios occurred at the uppermost sample mostly consisting of fresh plant material. Beneath, in the SkyI record the index sharply increased and $\mathrm{C} / \mathrm{N}$ decreased to a plateau. In the SkyII peat, the humification index was lowest compared to the other sites, generally increasing with depth, but peaks seemed to be positioned near ash layers (Fig. 4). Ratios of $\mathrm{C} / \mathrm{N}$ were mostly inversely related to the humification index down to a depth of $150 \mathrm{~cm}$. Below, $\mathrm{C} / \mathrm{N}$ ratios decreased only slightly with depth, in spite of consistently increasing humification.

\subsection{Dissolved organic carbon (DOC)}

DOC concentrations ranged from $<30 \mathrm{mg} \mathrm{l}^{-1}$ to $160 \mathrm{mg}^{-1}$ and mostly increased with depth (Fig. 4), as observed for the humification index in the solid peat (see correlations in Table 3). The three sites had similar concentrations in the up-

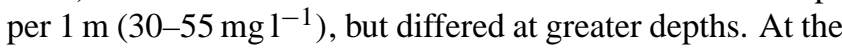


Table 3. Correlation coefficients after Pearson $(r)$, with $N$ as number of sample. Asterisks indicate different levels of significance. Only significant correlations are shown.

\begin{tabular}{|c|c|c|c|c|c|}
\hline & & FTIR 1720/1090 & FTIR 1630/1090 & FTIR 1510/1090 & FTIR 1420/1090 \\
\hline FTIR 1720/1090 & $\begin{array}{l}r \\
N\end{array}$ & - & & & \\
\hline \multirow[t]{2}{*}{ FTIR 1630/1090 } & $r$ & $0.937^{b}$ & - & & \\
\hline & $N$ & 77 & & & \\
\hline \multirow[t]{2}{*}{ FTIR 1510/1090 } & $r$ & $0.834^{\mathrm{b}}$ & $0.933^{b}$ & - & \\
\hline & $N$ & 77 & 77 & & \\
\hline \multirow[t]{2}{*}{ FTIR 1420/1090 } & $r$ & $0.921^{\mathrm{b}}$ & $0.972^{b}$ & $0.974^{\mathrm{b}}$ & - \\
\hline & $N$ & 77 & 77 & 77 & \\
\hline \multirow[t]{2}{*}{$\mathrm{DOC}\left[\mathrm{mg} \mathrm{l}^{-1}\right]$} & $r$ & & & $0.505^{\mathrm{b}}$ & $0.452^{\mathrm{a}}$ \\
\hline & $N$ & & & 29 & 29 \\
\hline \multirow[t]{2}{*}{ Peat N [\%] } & $r$ & $0.571^{\mathrm{b}}$ & $0.625^{\mathrm{b}}$ & $0.549^{b}$ & $0.540^{\mathrm{b}}$ \\
\hline & $N$ & 60 & 60 & 60 & 60 \\
\hline \multirow[t]{2}{*}{ Peat C [\%] } & $r$ & $0.715^{\mathrm{b}}$ & $0.655^{\mathrm{b}}$ & $0.566^{\mathrm{b}}$ & $0.653^{b}$ \\
\hline & $N$ & 60 & 60 & 60 & 60 \\
\hline \multirow[t]{2}{*}{$\delta^{13} \mathrm{C}[\% \circ]$} & $r$ & $-0.311^{\mathrm{a}}$ & $-0.303^{\mathrm{a}}$ & $-0.357^{\mathrm{b}}$ & $-0.325^{\mathrm{a}}$ \\
\hline & $N$ & 60 & 60 & 60 & 60 \\
\hline \multirow[t]{2}{*}{ Peat $\mathrm{C} / \mathrm{N}$} & $r$ & $-0.446^{\mathrm{b}}$ & $-0.546^{\mathrm{b}}$ & $-0.490^{\mathrm{b}}$ & $-0.469^{b}$ \\
\hline & $N$ & 60 & 60 & 60 & 60 \\
\hline
\end{tabular}

${ }^{\mathrm{a}}$ Correlation is significant on a level of 0.05 (2-tailed). ${ }^{\mathrm{b}}$ Correlation is significant on a level of 0.01 (2 tailed).

$\mathrm{PBr} 2$

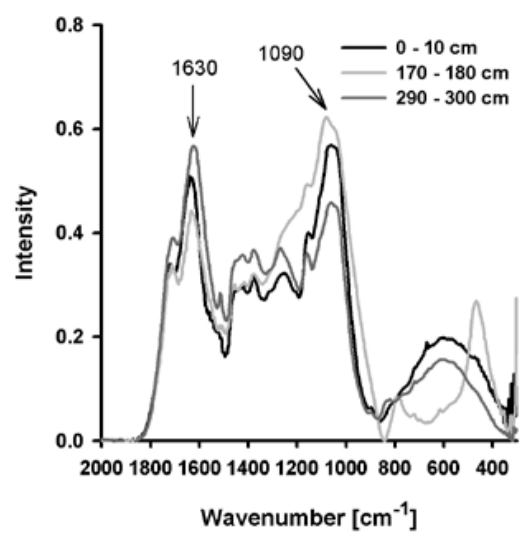

Skyl

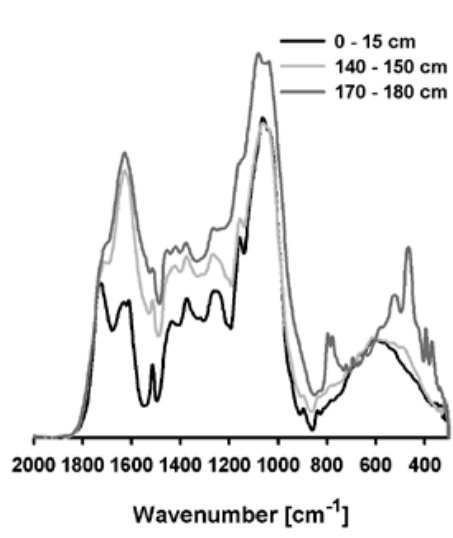

Skyll

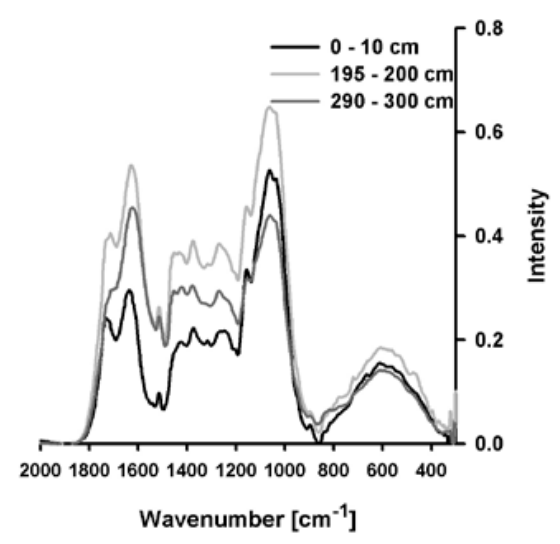

Fig. 3. FTIR-spectra of peat samples from the three bogs in different depths. Chosen samples represent upper, less decomposed peat $(0-10 \mathrm{~cm})$, deeper, highly decomposed peat and samples influenced by ash layer or underlying sediment (Pbr2 170-180 cm and SkyI 170$180 \mathrm{~cm})$.

$\mathrm{PBr} 2$ site, concentrations were lowest, increased little with depth up to a concentration of $64 \mathrm{mg} \mathrm{l}^{-1}$ and followed more the pattern of $\mathrm{C} / \mathrm{N}$. In contrast, at the Sky sites, DOC concentrations followed the trend of the FTIR humification index. Concentrations of DOC at the SkyI site peaked at $160 \mathrm{~cm}$ near the peat base at $148 \mathrm{mgl}^{-1}$. The SkyII bog showed highest concentrations and the greatest gradient of all sites and peaked at $245 \mathrm{~cm}$ depth at $258 \mathrm{mg} \mathrm{l}^{-1}$. This peak coincided with a volcanic ash layer and a high degree of humification. Below this ash layer DOC concentrations decreased again. Values of $\mathrm{C} / \mathrm{N}$ of the $\mathrm{DOC}$ were generally lower than $\mathrm{C} / \mathrm{N}$ in the solid phase (Fig. 4).

\subsection{Carbon and nitrogen Isotope signatures}

Carbon isotope signatures in the solid phase at all sites were around $\sim-26.5 \pm 1 \%$ with exception of a lower value in the uppermost sample (fresh vegetation) of the SkyI site (Fig. 4). Values only weakly correlated with C/N (SkyI, leaving out the vegetation sample) or inversely with FTIR humification indices (SkyII and lumped data, $\mathrm{PBr} 2$ not significant) and 


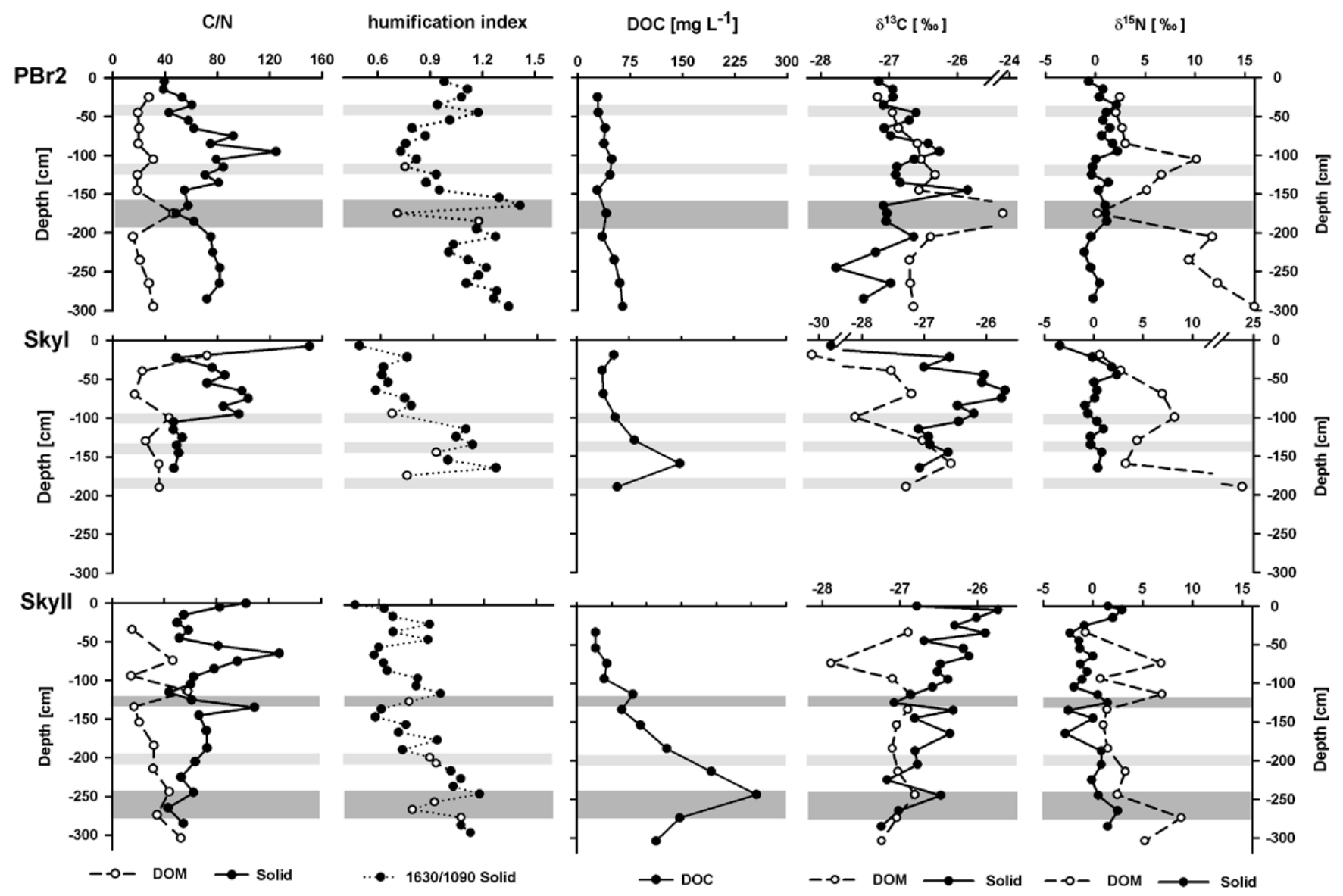

Fig. 4. $\mathrm{C} / \mathrm{N}$ ratios of solid peat and DOM, FTIR derived humification indices (ratios of absorption at wavenumbers 1630/1090), DOC concentrations, $\delta^{13} \mathrm{C}$ and $\delta^{15} \mathrm{~N}$ of solid peat and DOM at the sites PBr2 (top), SkyI (middle), and SkyII (bottom). Grey bands denote ash layers. Open symbols in profiles of humification indices indicate samples possibly influenced by ash deposits and need to be interpreted with caution.

correlations are thus not presented. Especially in uppermost samples and near ash layers ( $\mathrm{PBr} 2$, SkyII) contrasting trends occurred. At the SkyI site, $\delta^{13} \mathrm{C}$ values increased to a maximum of $-25.7 \%$ at $75 \mathrm{~cm}$ and decreased again below, following the $\mathrm{C} / \mathrm{N}$ pattern. At the SkyII site, signatures on average decreased with depth and only partly followed the $\mathrm{C} / \mathrm{N}$ pattern. In the $\mathrm{PBr} 2$ record, there was no trend in $\delta^{13} \mathrm{C}$ values over depth and the $\delta^{13} \mathrm{C}$ pattern partly followed $\mathrm{C} / \mathrm{N}$ ratios, partly the humification index. Isotope signatures of vegetation samples varied between $-24.5 \%$ and $-29.2 \%$ for carbon and between $-11.2 \%$ to $1.2 \%$ o for nitrogen (Table 4 ). The $\delta^{15} \mathrm{~N}$ signatures in the peat solid phase fluctuated between $-3 \% o$ and $+3 \%$ over depth and could not be related to any decomposition index.

Values of $\delta^{13} \mathrm{C}$ in the DOC fraction ranged from -28.1 to $-24.4 \%$. Values at the $\mathrm{PBr} 2$ site were again less negative $(\sim-26.7 \%$ ) compared to the other two bogs (SkyI $\sim-27.3 \%$ and SkyII $\sim-27.1 \%$ o). Highest ${ }^{13} \mathrm{C}$ content coincided with presence of an ash layer at $175 \mathrm{~cm}(\mathrm{PBr} 2)$ or $250 \mathrm{~cm}$ (SkyII), strongest ${ }^{13} \mathrm{C}$ depletion was observed in the upper profile at the Sky bogs. Values of $\delta^{13} \mathrm{C}$ for DOC were similar or more negative than for the solid peat at the SkyI and the SkyII site. Contrarily, at the $\mathrm{PBr} 2$ site, $\delta^{13} \mathrm{C}$ of DOC were either similar to or less negative compared to solid peat carbon.

DON was consistently and increasingly enriched in ${ }^{15} \mathrm{~N}$ with depth by 2 to $15 \%$ compared to solid phase nitrogen. Values of $\delta^{15} \mathrm{~N}$ in DON were inversely correlated with solid phase $\delta^{15} \mathrm{~N}$ at the PBr2 site $(p<0.05)$, and positively correlated with the FTIR derived humification index for the lumped dataset and for the $\mathrm{PBr} 2$ site $(p<0.01$ and $p<0.05$, respectively).

\section{Discussion}

\subsection{Peat decomposition}

Taking the FTIR measurements as a parameter to describe qualitative changes of organic matter during decomposition (Cocozza et al., 2003; Kalbitz et al., 1999), we could observe 
Table 4. Carbon and nitrogen isotope signatures and $\mathrm{C} / \mathrm{N}$ of different plants of the SkyI site in comparison to values evaluated by Kleinebecker et al. (2009) at bogs in southern Patagonia.

\begin{tabular}{lrrr}
\hline Species & $\delta^{13} \mathrm{C}[\%]$ & $\delta^{15} \mathrm{~N}[\% \circ]$ & $\mathrm{C} / \mathrm{N}$ \\
\hline Astelia pumila & $-26.5^{\mathrm{a}} /-26.0^{\mathrm{b}}$ & $-5.4^{\mathrm{a}} /-5.6^{\mathrm{b}}$ & $74^{\mathrm{a}} / 43^{\mathrm{b}}$ \\
Empetrum rubrum & $-28.7^{\mathrm{a}} /-28.2^{\mathrm{b}}$ & $-11.2^{\mathrm{a}} /-9.7^{\mathrm{b}}$ & $104^{\mathrm{a}} / 71^{\mathrm{b}}$ \\
Marsippospermum grandiflorum & $-24: 5^{\mathrm{a}} /-25.3^{\mathrm{b}}$ & $1.2^{\mathrm{a}} / 2.3^{\mathrm{b}}$ & $36^{\mathrm{a}} / 46^{\mathrm{b}}$ \\
Nothofagus betuloides & $-29.2^{\mathrm{a}}$ & $-3.4^{\mathrm{a}}$ & $77^{\mathrm{a}}$ \\
Sphagnum magellanicum & $-29.1^{\mathrm{a}} /-27.0^{\mathrm{b}}$ & $-1.0^{\mathrm{a}} /-4.7^{\mathrm{b}}$ & $134^{\mathrm{a}} / 89^{\mathrm{b}}$ \\
Tetronicum magellanicum & $-27.2^{\mathrm{a}}$ & $0.8^{\mathrm{a}}$ & $83^{\mathrm{a}}$ \\
\hline
\end{tabular}

a this study (standard error for repeated measurements of $\delta^{15} \mathrm{~N}:<0.5 \%$ and $\delta^{13} \mathrm{C}:<0.25 \%$ ) ${ }^{\mathrm{b}}$ mean values from Kleinebecker et al. (2009); C/N was calculated by mean total carbon and nitrogen content.

a generally increasing humification index with depth at all three sites. This pattern had previously been reported for northern temperate peatlands (Beer et al., 2008; Cocozza et al., 2003). We also expected the $\mathrm{C} / \mathrm{N}$ ratio as an indicator of peat mass loss during decomposition (Kuhry and Vitt, 1996) to be inversely related to humification, i.e. lower $\mathrm{C} / \mathrm{N}$ values with an increasing humification index. Indeed these two parameters were negatively correlated at our sites $(\mathrm{C} / \mathrm{N}$ to 1630/1090; $r=0.546$, see Table 3). However, in contrast to the FTIR-ratios, $\mathrm{C} / \mathrm{N}$ ratios were not significantly correlated with depth, and deviations of the two decomposition parameters occurred as reported in the study of Borgmark and Schoning (2006). Ratios of $\mathrm{C} / \mathrm{N}$ mainly ranged from 40 to 100 , which is comparable to previously reported values for bog vegetation and peat (e.g. Hornibrook et al., 2000; Biester et al., 2003; Malmer and Holm, 1984). Lowest humification indices of the three investigated bogs occurred at the Sphagnum dominated SkyII bog, probably as Sphagnum yields refractory litter of high polyphenol content and high $\mathrm{C} / \mathrm{N}$ ratios (Bragazza et al., 2007). In both Sky bogs a steep increase of humification $(\sim 0.5$ to 0.8$)$ and decrease in $\mathrm{C} / \mathrm{N}$ was detected down to depths of $20-40 \mathrm{~cm}$, as decomposition is typically fast in the unsaturated zone (Clymo, 1984; Kuhry and Vitt, 1996). This was less obvious in the $\mathrm{PBr} 2$ profile, where high humification indices and low $\mathrm{C} / \mathrm{N}$ ratio values occurred in the upper $50 \mathrm{~cm}$, suggesting increased decomposition and less peat accumulation in the last hundreds of years. Humification indices from FTIR measurements in the peat of the $\mathrm{PBr} 2$ site ( 0.7 to 1.4 ) exceeded values observed at the other sites, but were still lower compared to values reported by Beer et al. (2008) for the Canadian Mer Bleue Bog (1.00 to 1.73 from 50 to $330 \mathrm{~cm}$ depth).

Changes in the humification index are typically interpreted to represent changes in decomposition processes in the acrotelm and therefore changes in environmental conditions, i.e. different climate and resulting differences in decomposition and peat accumulation (Borgmark and Schoning, 2006; Kuhry and Vitt, 1996; McCulloch and Davies, 2001).

In the SkyI bog two different phases of decomposition occurred based on both the humification index and $\mathrm{C} / \mathrm{N}$ ratio.
In the upper peat profile from $30-100 \mathrm{~cm}$ the humification index was low, around 0.7 , and $\mathrm{C} / \mathrm{N}$ high, between 60 and 100. This suggests rapid peat growth under wet conditions (Borgmark and Schoning, 2006; Kuhry and Vitt, 1996). Below $100 \mathrm{~cm}$ peat decomposition was more advanced, which may indicate that the bog was drier during this time period and the peat exposed to aerobic decay for longer periods of time (Borgmark and Schoning, 2006). On the other hand the deeper peat may also have originated from a minerotrophic fen, as described in Kilian et al. (2003) for the center of the bog.

In contrast, at the $\mathrm{PBr} 2$ site peat was more decomposed in the upper $75 \mathrm{~cm}$ and below $150 \mathrm{~cm}$, i.e. $\mathrm{C} / \mathrm{N}$ ratios were low and humification index high. For the uppermost peat and minding current peat forming vegetation containing sedges and rushes with lower $\mathrm{C} / \mathrm{N}$, this could be due to more easily decomposable litter. The obvious differences in vegetation were explained by less precipitation and higher nutrient supply through sea spray input at the site (Kleinebecker et al., 2007, 2008). The increase in decomposition could also be caused by temporarily drier conditions at the site (Borgmark and Schoning, 2006), as would be supported by $\delta^{13} \mathrm{C}$ results (see below). Peat was particularly strongly decomposed near the ash layer at $175 \mathrm{~cm}$. Between 75 and $150 \mathrm{~cm}$ depth peat had apparently accumulated more rapidly, as we infer from high $\mathrm{C} / \mathrm{N}$ ratios and a low humification index. Biester et al. (2003) reported similar $\mathrm{C} / \mathrm{N}$ ratios for the $\mathrm{PBr} 2$ site and found the same pattern of decomposition. In this study, the authors attributed changes in $\mathrm{C} / \mathrm{N}$ ratios primarily to changes in bog wetness and associated changes in decomposition, but also hypothesized a stimulating effect of ash deposition on peat decomposition.

In the SkyII bog the humification index increased with depth with some fluctuations but this trend was less visible in $\mathrm{C} / \mathrm{N}$ ratios. Two ash layers apparently accelerated decomposition processes also here since low $\mathrm{C} / \mathrm{N}$ ratios and high humification indices occurred above the ash layers. Noticeable were two peaks of high $\mathrm{C} / \mathrm{N}$ ratios and low humification, i.e. rapid peat growth at $50-75 \mathrm{~cm}$ and $140-150 \mathrm{~cm}$ depth, following the suggested interpretation of Kuhry and Vitt (1996). 
Unfortunately, as no plant macrofossil records exist for the sites, effects of shifts in vegetation and thus litter input as possible causes cannot be ruled out.

\subsection{Decomposition and isotopic signatures of solid peat}

Carbon isotope ratios in the solid phase varied only in a narrow range of $2 \%$ around $-26.5 \%$, despite larger relative differences of decomposition degree with depth. Differences between the investigated sites were small. Values and variation of $\delta^{13} \mathrm{C}$ fell into the range found in our vegetation and reported for Sphagnum and other vegetation (Hornibrook et al., 2000; Rice and Giles, 1996; Price et al., 1997; Kleinebecker et al., 2009). With few exceptions peat was generally depleted in ${ }^{13} \mathrm{C}$ with depth. As $\delta^{13} \mathrm{C}$ values were mostly low in more decomposed peat and decomposition processes should result in $\delta^{13} \mathrm{C}$ enrichment in the residual peat (Nadelhoffer and Fry, 1988; Novak et al., 1999), the $\delta^{13} \mathrm{C}$ record was thus not the result of decomposition (see also Jones et al., 2010). It probably reflects other factors, such as changes in the vegetation (Hornibrook et al., 2000), moisture (Novak et al., 2010; Loisel et al., 2010) or temperature (Jedrysek and Skrzypek, 2005; Skrzypek et al., 2007) during peat formation. Drier or warmer conditions, for example, lead to a more negative carbon isotope signature in bulk peat stemming from moss litter according to the latter studies. Dry conditions would also result in faster decomposition, i.e. lower $\mathrm{C} / \mathrm{N}$ ratios and high humification indices in the peat record (Borgmark and Schoning, 2006). Thus, comparing $\delta^{13} \mathrm{C}$ data and decomposition indices, dry phases may be postulated for the upper meter and below $150 \mathrm{~cm}$ at the $\mathrm{PBr} 2$ site, below $100 \mathrm{~cm}$ at the SkyI site and below $200 \mathrm{~cm}$ at the SkyII site.

Values of $\delta^{13} \mathrm{C}$ in peat can, however, also be affected by plant uptake of recycled carbon from methane, an effect that is highly variable (Price et al., 1997; Raghoebarsing et al., 2005), but may especially occur under warmer and wetter conditions (Jones et al., 2010). Furthermore, low $\delta^{13} \mathrm{C}$ values, as observed at the bottom part of the SkyI profile, could also be due to a minerotrophic origin of the peatland, as low $\delta^{13} \mathrm{C}$ in bulk peat were also observed in a minerotrophic site (Knorr et al., 2008) or in phases of minerotrophy (Jones et al., 2010). To infer climatic signals from peat profiles without reservations is thus difficult and should not be based on one index of decomposition or isotope records only.

Values of $\delta^{15} \mathrm{~N}$ in the solid phase ranged from -3 to $+3 \%$, as also observed by Novak et al. (1999), but were neither related to decomposition degree nor to $\mathrm{N}$ contents. Greatest changes occurred in the upper $5-10 \mathrm{~cm}$, which is probably due to the comparably wide range of $\delta^{15} \mathrm{~N}$ of the vegetation (Table 4) (Kleinebecker et al., 2009). Deeper into the peat $\delta^{15} \mathrm{~N}$ values were rather constant around $0 \%$. This is not surprising, as atmospheric $\mathrm{N}$ was probably the primary $\mathrm{N}$ source (Jones et al., 2010). It has to be noted, though, that data on $\mathrm{N}$ fixation activity and its contribution to total $\mathrm{N}$ inputs in peat- lands are scarce (e.g. Kravchenko and Doroshenko, 2003). Only few $\delta^{15} \mathrm{~N}$ values have been reported so far for the investigated depths and the use of $\delta^{15} \mathrm{~N}$ measurements to trace decomposition in solid peat is so far not well constrained.

\subsection{Volcanic ash layers and their impact on decomposition}

Kilian et al. (2003) investigated ash layers at the PBr2 and SkyI sites. The most prominent ash layer in these bogs originated from an eruption of Mt. Burney dated to $4254 \pm 120$ cal. yr BP in Kilian et al. (2003). We identified this layer due to its thickness in $175 \mathrm{~cm}$ depth at the $\mathrm{PBr} 2$ and $265 \mathrm{~cm}$ in the SkyII record. All other volcanic eruptions, which could be recorded in our peat cores led to less ash deposition, were dispersed by root growth after deposition, and could not be easily distinguished. Therefore, we could use the Mt. Burney ash layer to compare peat accumulation for the latter two sites. In the SkyI record, no such prominent ash layer occurred as expected from the Mt. Burney eruption.

Biester et al. (2003) reported peat accumulation rates for the PBr2 and SkyI bog (Table 5). The rates are in agreement with our interpretations because the accumulation rates at a site were low when we found more decomposed peat. The authors reported very low peat accumulation just above the Mt. Burney ash layer in their PBr2 profile (147$216 \mathrm{~cm}$ ), where the peat was most strongly decomposed in this study. Phases of the higher accumulation rates coincided with phases of lower peat decomposition. No accumulation rates are available for the SkyII bog, but comparing the depth of the $4250 \mathrm{yr}$ BP tephra layer, it occurred at $265 \mathrm{~cm}$ depth, $\sim 90 \mathrm{~cm}$ deeper than in the $\mathrm{PBr} 2 \mathrm{bog}$. This indicates a greater overall accumulation of peat over the last $4000 \mathrm{yr}$, which is in accordance with the lower degree of decomposition in the SkyII bog. Using the Mt. Burney ash layer as a reference the SkyII bog on average accumulated about $0.06 \mathrm{~cm} \mathrm{yr}^{-1}$ and the PBr2 bog $0.04 \mathrm{~cm} \mathrm{yr}^{-1}$ from that time on (Table 1).

The ash layers obviously had an influence on the degree of decomposition in the peat profiles. We want to point out that the very low values of the humification index within in the ash layer should not be taken in account, because of interferences of minerals in the FTIR-spectra (Marel and Beutelspacher, 1976). Excluding samples affected by mineral components, especially above the Mt. Burney eruption around $4250 \mathrm{yr} \mathrm{BP}$ we observed a high humification index and medium to low $\mathrm{C} / \mathrm{N}$ ratios in the $\mathrm{PBr} 2$ and SkyII record. Above the second prominent ash layer at $125 \mathrm{~cm}$ in the SkyII record, the $\mathrm{C} / \mathrm{N}$ ratio and the humification index again peaked, albeit more weakly. Biester et al. (2003) suggested that low $\mathrm{C} / \mathrm{N}$ values determined above tephra layers could be a result of increased decomposition due to the nutrient-rich ash deposition. This could result in enhanced microbial activity and organic matter mineralization. Hotes et al. (2010) reported an increase in $\mathrm{pH}$, electric conductivity, sulfate and sodium concentrations, as well as nutrient release 
Table 5. Peat accumulation rates for the PBr2 and SkyI bogs from Biester et al. (2003) and peat ages from Kilian et al. (2003) since the beginning of ombrotrophic peat growth. Mean estimated peat accumulation rates determined in this study for PBr2 and SkyII are given at the table bottom.

\begin{tabular}{|c|c|c|c|c|c|c|c|c|}
\hline \multicolumn{4}{|c|}{$\mathrm{PBr} 2$} & \multicolumn{4}{|c|}{ SkyI } & \multirow[t]{3}{*}{ SkyII } \\
\hline \multirow[t]{2}{*}{$\begin{array}{l}\text { Depth } \\
{[\mathrm{cm}]}\end{array}$} & \multirow[t]{2}{*}{$\begin{array}{l}\text { Peat accum. } \\
{\left[\mathrm{cm} \mathrm{yr}^{-1}\right]}\end{array}$} & \multicolumn{2}{|c|}{$\begin{array}{c}\text { Peat age } \\
\text { [cal. yr BP] }\end{array}$} & \multirow[t]{2}{*}{$\begin{array}{l}\text { Depth } \\
{[\mathrm{cm}]}\end{array}$} & \multirow[t]{2}{*}{$\begin{array}{l}\text { Peat accum. } \\
{\left[\mathrm{cm} \mathrm{yr}^{-1}\right]}\end{array}$} & \multicolumn{2}{|c|}{$\begin{array}{c}\text { Peat age } \\
\text { [cal. yr BP] }\end{array}$} & \\
\hline & & Depth $[\mathrm{cm}]$ & Age & & & Depth $[\mathrm{cm}]$ & Age & \\
\hline $0-63$ & 0.057 & & & $0-68$ & 0.062 & 68 & 858 & \\
\hline $63-147$ & 0.133 & 70 & 855 & $68-120$ & 0.069 & 120 & 1846 & \\
\hline $147-216$ & 0.025 & 148 & 1481 & $120-244$ & 0.026 & 244 & 5952 & \\
\hline $216-480$ & 0.036 & 480 & 10883 & & & & & \\
\hline $\begin{array}{l}\text { estimated } \\
\text { peat acc.* }\end{array}$ & $\begin{array}{c}0.04 \\
(175 \mathrm{~cm})\end{array}$ & & & & & & & $\begin{array}{c}0.06 \\
(265 \mathrm{~cm})\end{array}$ \\
\hline
\end{tabular}

* Calculated by the depth of the Mt. Burney eruption ash deposit (values given in brackets) divided by time (4250 yr BP according to Kilian et al., 2003).

from decomposing plant material after volcanic ash deposition. After deposition, alkali loss is a typical phenomenon due to glass alteration of the tephra (Kilian et al., 2003 and references therein). An input of electron acceptors, such as sulfate, could further lead to alkalinity production during reduction under anaerobic conditions (McLaughlin and Webster, 2010), resulting in higher $\mathrm{pH}$ and a faster decomposition.

McCulloch and Davies (2001) investigated a bog nearby the $\mathrm{PBr} 2$ site at Puerto del Hambre and interpreted phases of highly humified peat as a result of drier climatic conditions. Climatic changes should have affected all three sites in a similar manner, and indeed decomposition indices and carbon stable isotope signatures support dryer or warmer conditions and intense decomposition above the Mount Burney ash deposit at the SkyII and PBr2 sites. Although these interpretations may be plausible it seems unlikely that paleoclimatic variations are the sole explanation of the decomposition patterns because the three sites' records are not very similar. In our profiles, interpretation of both the decomposition indices and $\delta^{13} \mathrm{C}$ signals in the upper $75 \mathrm{~cm}$ of the $\mathrm{PBr} 2$ site would suggest drier conditions, whereas the opposite conclusion must be drawn from the SkyII site (Fig. 4). Thus, climate induced signals at the sites may be masked by local variations in decomposition and influence of ash layers. Most obvious, diminished peat accumulation in the upper profile due to strong decomposition and drier conditions at the $\mathrm{PBr} 2$ site was not observed at the other sites. Decomposition indices and stable isotope records seemed to reflect changes in rather local, site-specific factors.

\subsection{Decomposition versus DOC concentrations and DOM isotopic signatures}

In spite of differences in peat decomposition degree, DOC concentrations were very similar in the upper meter of all three sites. Deeper into the peat larger differences occurred. DOC concentrations observed at the $\mathrm{PBr} 2$ site agreed with reported DOC concentration ranges of 20 to $60 \mathrm{mg} \mathrm{l}^{-1}$ for northern peatlands (Blodau, 2002). At the Sky sites concentrations increased with depth by a factor of 3 (SkyI) and 5 (SkyII) and reached $>250 \mathrm{mgl}^{-1}$. DOC concentrations $>200 \mathrm{mg}^{-1}$ have rarely been reported (e.g. in Clymo and Bryant, 2008).

A negative relation of DOM concentrations with the degree of peat decomposition has been reported (Kalbitz and Geyer, 2002; Biester et al., 2006). Generally, concentrations at the $\mathrm{PBr} 2$ site, with the highest humification index, were also low. Concentrations positively correlated with $\mathrm{C} / \mathrm{N}$ ratios $(r=0.712, p<0.05)$, as described in the study of Biester et al. (2006) before for this site. Highest DOC concentrations occurred at the SkyII site, with lowest humification index. In both Sky sites, however, concentrations correlated positively with the FTIR derived humification index $(1630 / 1090$ ratio, $r=0.839, p<0.01$ for the SkyII site; $r=0.839, p<0.05$ for the SkyI site), which is in conflict with the mentioned earlier work.

A redistribution of DOM could explain this discrepancy, but seems unlikely based on the low hydraulic conductivities and the low diffusion coefficient of DOM in the deeper peat (Beer et al., 2008; Biester et al., 2006; Cornel et al., 1986). Hydraulic conductivities ranged from $10^{-8}$ to $10^{-6} \mathrm{~m} \mathrm{~s}^{-1}$ and were low compared to other peat bogs, where often $10^{-6} \mathrm{~m} \mathrm{~s}^{-1}$ to $10^{-5} \mathrm{~m} \mathrm{~s}^{-1}$ were found (Baird et al., 2008; Chason and Siegel, 1986). Elevated DOM concentrations occurred near ash layers, in the deeper peat potentially formed under minerotrophic conditions, and in zones of intense decomposition at the Sky sites, but not at the $\mathrm{PBr} 2$ bog. The factors that control DOC concentration are thus difficult to identify from our data and the relationship between DOM concentrations and decomposition indices of solid peat seems to be poorly constrained.

Kalbitz and Geyer (2002) related enhanced humification of DOM itself to an enrichment of ${ }^{13} \mathrm{C}$ in DOM. This could partly be confirmed by our data, as the $\delta^{13} \mathrm{C}$ and the $\mathrm{C} / \mathrm{N}$ 
ratio in the DOM were correlated $(p<0.05)$ at the $\mathrm{PBr} 2$ and SkyI sites but not at the SkyII site. Clymo and Bryant (2008) found DOM to be consistently enriched in ${ }^{13} \mathrm{C}$ compared to the solid peat. In our data, in the Sky bogs DOM was depleted in ${ }^{13} \mathrm{C}$, but approached values of the solid phase with depth. In the more decomposed peat of the $\mathrm{PBr} 2$ bog, DOM became enriched in ${ }^{13} \mathrm{C}$ with depth compared to the solid phase. Thus, there was a relative enrichment of ${ }^{13} \mathrm{C}$ in DOM with depth, indicating preferential loss of ${ }^{12} \mathrm{C}$ during microbial modification. This was further supported by low $\mathrm{C} / \mathrm{N}$ and increasing enrichment of ${ }^{15} \mathrm{~N}$ in DOM. The latter indicates a repeated microbial recycling of $\mathrm{N}$ in DOM, which would be in line with a strong $\mathrm{N}$ deficiency at the sites and an enrichment of ${ }^{15} \mathrm{~N}$ due to higher humification (Dijkstra et al., 2008). In contrast, Kalbitz and Geyer (2002) found low $\delta^{15} \mathrm{~N}$ values in highly humified DOM, but this may be explained by a varying contribution of DON supply from either the solid phase or organic matter mineralization.

\section{Conclusions}

The study demonstrated both similarities and differences in peat decomposition records of the investigated peatlands. The deep peat was most strongly decomposed at all sites as indicated by the FTIR humification index, but small variations over depth reflected frequent changes in controlling conditions over time. As the individual decomposition records of the sites differed in spite of their proximity, an interpretation of the data with respect to bog wetness and its impact on decomposition seems to be limited by local, site specific factors. Advanced decomposition within the depth profiles seemed to be related to ash deposits and possibly also to the effects of sea spray input, resulting in concomitant changes in vegetation litter chemistry, nutrient contents or electron acceptor inputs for anaerobic respiration. Regarding decomposition indices, not all phases of increased decomposition and - following common interpretation of $\delta^{13} \mathrm{C}$ data - not all phases of drier or warmer conditions, respectively, were reflected in all profiles. Effects of ash deposits or also phases of minerotrophy may thus have been more important for changes in decomposition indices and $\delta^{13} \mathrm{C}$ of the peat. Relative enrichment of ${ }^{13} \mathrm{C}$ in DOM compared to the surrounding peat reflected a preferential loss of ${ }^{12} \mathrm{C}$ due to mineralization of DOM. Enrichment of ${ }^{15} \mathrm{~N}$ in DOM and consistent trends with solid peat $\mathrm{C} / \mathrm{N}$ ratios over depth suggested microbial recycling of $\mathrm{N}$ under $\mathrm{N}$ deficient conditions. DOM concentration did not serve as a decomposition index in a consistent way.

Acknowledgements. This study was in part supported by Deutsche Forschungsgemeinschaft (DFG) grants to H. Biester and C. Blodau, a travel grant of the Deutsche Gesellschaft für Limnologie (DGL) to K. H. Knorr. Stable isotope measurements were conducted at the BayCEER Laboratory of Isotope-Biogeochemistry, headed by Gerhard Gebauer. The assistance of Silke Hammer, Martina Rohr,
Karin Söllner, Heidi Zier, Yvonne Hermanns and Ina Reisen is greatly acknowledged.

Edited by: R. Conant

\section{References}

Aselmann, I. and Crutzen, P. J.: Global distribution of natural freshwater wetlands and rice-paddies, their net primary productivity, seasonality and possible methane emissions, J. Atmos. Chem., 8, 307-358, 1989.

Baird, A. J., Eades, P. A., and Surridge, B. W. J.: The hydraulic structure of a raised bog and its implications for ecohydrological modelling of bog development, Ecohydrology, 1, 289-298, doi:10.1002/eco.33, 2008.

Beer, J. and Blodau, C.: Transport and thermodynamics constrain belowground carbon turnover in a northern peatland, Geochim. Cosmochim. Acta, 71, 2989-3002, doi:10.1016/j.gca.2007.03.010, 2007.

Beer, J., Lee, K., Whiticar, M., and Blodau, C.: Geochemical controls on anaerobic organic matter decomposition in a northern peatland, Limnol. Oceanogr., 53, 1393-1407, 2008.

Biester, H., Martinez-Cortizas, A., Birkenstock, S., and Kilian, R.: Effect of peat decomposition and mass loss on historic mercury records in peat bogs from patagonia, Environ. Sci. Technol., 37, 32-39, doi:10.1021/es025657u, 2003.

Biester, H., Keppler, F., Putschew, A., Martinez-Cortizas, A., and Petri, M.: Halogen retention, organohalogens, and the role of organic matter decomposition on halogen enrichment in two chilean peat bogs, Environ. Sci. Technol., 38, 1984-1991, doi:10.1021/es0348492, 2004.

Biester, H., Selimovic, D., Hemmerich, S., and Petri, M.: Halogens in pore water of peat bogs - the role of peat decomposition and dissolved organic matter, Biogeosciences, 3, 53-64, doi:10.5194/bg-3-53-2006, 2006.

Blodau, C.: Carbon cycling in peatlands - a review of processes and controls, Environ. Rev., 10, 111-134, doi:0.1139/A02-004, 2002.

Borgmark, A. and Schoning, K.: A comparative study of peat proxies from two eastern central swedish bogs and their relation to meteorological data, J. Quaternary Sci., 21, 109-114, doi:10.1002/jqs.959, 2006.

Bragazza, L., Siffi, C., Iacumin, P., and Gerdol, R.: Mass loss and nutrient release during litter decay in peatland: The role of microbial adaptability to litter chemistry, Soil Biol. Biochem., 39, 257-267, doi:10.1016/j.soilbio.2006.07.014, 2007.

Bridgham, S. D., Pastor, J., Updegraff, K., Malterer, T. J., Johnson, K., Harth, C., and Chen, J. Q.: Ecosystem control over temperature and energy flux in northern peatlands, Ecol. Appl., 9, 13451358, 1999.

Chason, D. B. and Siegel, D. I.: Hydraulic conductivity and related physical properties of peat, lost river peatland, northern Minnesota, Soil Sci., 142, 91-99, 1986.

Clymo, R. S.: The limits to peat bog growth, Philos. T. Roy. Soc. B, 303, 605-654, 1984.

Clymo, R. S. and Bryant, C. L.: Diffusion and mass flow of dissolved carbon dioxide, methane, and dissolved organic carbon in a 7-m deep raised peat bog, Geochim. Cosmochim. Acta, 72, 2048-2066, doi:10.1016/j.gca.2008.01.032, 2008. 
Cocozza, C., D’Orazio, V., Miano, T. M., and Shotyk, W.: Characterization of solid and aqueous phases of a peat bog profile using molecular fluorescence spectroscopy, ESR and FT-IR, and comparison with physical properties, Org. Geochem., 34, 49-60, 2003.

Cornel, P. K., Summers, R. S., and Roberts, P. V.: Diffusion of humic-acid in dilute aqueous solution, J. Colloid Interface Sci., 110, 149-164, 1986.

Damman, A. W. H.: Regulation of nitrogen removal and retention in sphagnum bogs and other peatlands, Oikos, 51, 291-305, 1988.

Dijkstra, P., LaViolette, C. M., Coyle, J. S., Doucett, R. R., Schwartz, E., Hart, S. C., and Hungate, B. A.: ${ }^{15} \mathrm{~N}$ enrichment as an integrator of the effects of $\mathrm{C}$ and $\mathrm{N}$ on microbial metabolism and ecosystem function, Ecol. Lett., 11, 389-397, doi:10.1111/j.1461-0248.2008.01154.x, 2008.

Fetter, C. W.: Applied hydrogeology, 4 ed., Prentice Hall, Upper Saddle River, NJ, 598 pp., 2001.

Fraser, C. J. D., Roulet, N. T., and Lafleur, M.: Groundwater flow patterns in a large peatland, J. Hydrol., 246, 142-154, 2001.

Freeman, C., Ostle, N., and Kang, H.: An enzymic "latch" on a global carbon store - a shortage of oxygen locks up carbon in peatlands by restraining a single enzyme, Nature, 409, 149-149, 2001.

Frolking, S., Roulet, N. T., Moore, T. R., Richard, P. J. H., Lavoie, M., and Muller, S. D.: Modeling northern peatland decomposition and peat accumulation, Ecosystems, 4, 479-498, 2001.

Godoy, R., Paulino, L., Oyarzún, C., and Boeckx, P.: Atmospheric $\mathrm{N}$ deposition in central and southern Chile: An overview, Gayana. Botánica, 60, 47-53, 2003.

Heusser, C. J., Heusser, L. E., Lowell, T. V., Moreira, A., and Moreira, S.: Deglacial palaeoclimate at puerto del hambre, subantarctic Patagonia, Chile, J. Quaternary Sci., 15, 101-114, 2000.

Hogg, E. H.: Decay potential of hummock and hollow sphagnum peats at different depths in a swedish raised bog, Oikos, 66, 269278, 1993.

Holmgren, A. and Norden, B.: Characterization of peat samples by diffuse reflectance FT-IR spectroscopy, Appl. Spectrosc., 42, 255-262, 1988.

Hornibrook, E. R. C., Longstaffe, F. J., Fyfe, W. S., and Bloom, Y.: Carbon-isotope ratios and carbon, nitrogen and sulfur abundances in flora and soil organic matter from a temperate-zone bog and marsh, Geochem. J., 34, 237-245, 2000.

Hotes, S., Grootjans, A. P., Takahashi, H., Ekschmitt, K., and Poschlod, P.: Resilience and alternative equilibria in a mire plant community after experimental disturbance by volcanic ash, Oikos, 119, 952-963, doi:10.1111/j.1600-0706.2009.18094.x, 2010.

IFM-GEOMAR, SFB 574, Leibnitz Institut für Meereswissenschaften an der Universität Kiel, https://sfb574.ifm-geomar. de/gmt-maps, last access: February 2011.

Jedrysek, M. O. and Skrzypek, G.: Hydrogen, carbon and sulphur isotope ratios in peat: The role of diagenessis and water regimes in reconstruction of past climates, Environ. Chem. Lett., 2, 179183, doi:10.1007/s10311-004-0093-4, 2005.

Jones, M. C., Peteet, D. M., and Sambrotto, R.: Late-glacial and holocene $\delta^{15} \mathrm{~N}$ and $\delta^{13} \mathrm{C}$ variation from a kenai peninsula, alaska peatland, Paleogeogr. Paleoclimatol. Paleoecol., 293, 132-143, doi:10.1016/j.palaeo.2010.05.007, 2010.
Kalbitz, K. and Geyer, S.: Different effects of peat degradation on dissolved organic carbon and nitrogen, Org. Geochem., 33, 319326, 2002.

Kalbitz, K., Geyer, W., and Geyer, S.: Spectroscopic properties of dissolved humic substances - a reflection of land use history in a fen area, Biogeochemistry, 47, 219-238, 1999.

Kalbitz, K., Geyer, S., and Gehre, M.: Land use impacts on the isotopic signature $\left({ }^{13} \mathrm{C},{ }^{14} \mathrm{C},{ }^{15} \mathrm{~N}\right)$ of water-soluble fulvic acids in a german fen area, Soil Sci., 165, 728-736, 2000.

Kilian, R., Hohner, M., Biester, H., Wallrabe-Adams, H. J., and Stern, C. R.: Holocene peat and lake sediment tephra record from the southernmost chilean andes $\left(53-55^{\circ} \mathrm{S}\right)$, Rev. Geol. Chile, 30, 23-37, 2003.

Kleinebecker, T., Holzel, N., and Vogel, A.: Gradients of continentality and moisture in south patagonian ombrotrophic peatland vegetation, Folia Geobot., 42, 363-382, 2007.

Kleinebecker, T., Holzel, N., and Vogel, A.: South patagonian ombrotrophic bog vegetation reflects biogeochemical gradients at the landscape level, J. Veg. Sci., 19, 151-160, doi:10.3170/20088-18370, 2008.

Kleinebecker, T., Schmidt, S. R., Fritz, C., Smolders, A. J. P., and Hölzel, N.: Prediction of $\delta^{13} \mathrm{C}$ and $\delta^{15} \mathrm{~N}$ in plant tissues with near-infrared reflectance spectroscopy, New Phytol., 184, 732739, doi:10.1111/j.1469-8137.2009.02995.x, 2009.

Knorr, K.-H., Glaser, B., and Blodau, C.: Fluxes and ${ }^{13} \mathrm{C}$ isotopic composition of dissolved carbon and pathways of methanogenesis in a fen soil exposed to experimental drought, Biogeosciences, 5, 1457-1473, doi:10.5194/bg-5-1457-2008, 2008.

Kravchenko, I. K. and Doroshenko, E. V.: Nitrogen-fixing activity in peat soils from a raised bog, Microbiology, 72, 98-102, 2003.

Kuhry, P. and Vitt, D. H.: Fossil carbon/nitrogen ratios as a measure of peat decomposition, Ecology, 77, 271-275, 1996.

Laiho, R.: Decomposition in peatlands: Reconciling seemingly contrasting results on the impacts of lowered water levels, Soil Biol. Biochem., 38, 2011-2024, doi:10.1016/j.soilbio.2006.02.017, 2006.

Loisel, J., Garneau, M., and Hélie, J. F.: Sphagnum $\delta^{13} \mathrm{C}$ values as indicators of palaeohydrological changes in a peat bog, Holocene, 20, 285-291, 2010.

Malmer, N. and Holm, E.: Variation in the C/N-quotient of peat in relation to decomposition rate and age determination with ${ }^{210} \mathrm{~Pb}$, Oikos, 43, 171-182, 1984.

Marel, H. W. v. d. and Beutelspacher, H.: Atlas of infrared spectroscopy of clay minerals and their admixtures, Elsevier Scientific Publishing Company, Amsterdam, 396 pp., 1976.

Markgraf, V.: Paleoenvironments and paleoclimates in tierra del fuego and southernmost patagonia, South America, Paleogeogr. Paleoclimatol. Paleoecol., 102, 53-68, 1993.

McCulloch, R. D. and Davies, S. J.: Late-glacial and holocene palaeoenvironmental change in the central strait of magellan, southern patagonia, Paleogeogr. Paleoclimatol. Paleoecol., 173, 143-173, 2001.

McLaughlin, J. W. and Webster, K. L.: Alkalinity and acidity cycling and fluxes in an intermediate fen peatland in northern Ontario, Biogeochemistry, 99, 143-155, 2010.

Nadelhoffer, K. F. and Fry, B.: Controls on natural ${ }^{15} \mathrm{~N}$ and ${ }^{13} \mathrm{C}$ abundances in forest soil organic matter, Soil Sci. Soc. Am. J., 52, 1633-1640, 1988. 
Niemeyer, J., Chen, Y., and Bollag, J. M.: Characterization of humic acids, composts, and peat by diffuse reflectance fouriertransform infrared-spectroscopy, Soil Sci. Soc. Am. J., 56, 135140, 1992.

Norden, B., Fyfe, C. A., and McKinnon, M. S.: ${ }^{13}$ C CP/MAS NMR study of peat in the solid state, International Peat Journal, 1, 153164, 1986.

Novak, M., Buzek, F., and Adamova, M.: Vertical trends in $\delta^{13} \mathrm{C}, \delta^{15} \mathrm{~N}$ and $\delta^{34} \mathrm{~S}$ ratios in bulk sphagnum peat, Soil Biol. Biochem., 31, 1343-1346, 1999.

Novak, M., Zemanova, L., Buzek, F., Jackova, I., Adamova, M., Komarek, A., Vile, M. A., Kelman Wieder, R., and Stepanova, M.: The effect of a reciprocal peat transplant between two contrasting Central European sites on $\mathrm{C}$ cycling and $\mathrm{C}$ isotope ratios, Biogeosciences, 7, 921-932, doi:10.5194/bg-7-921-2010, 2010.

Pancost, R. D., Baas, M., van Geel, B., and Damste, J. S. S.: Response of an ombrotrophic bog to a regional climate event revealed by macrofossil, molecular and carbon isotopic data, Holocene, 13, 921-932, doi:10.1191/0959683603hl674rp, 2003.

Price, G. D., McKenzie, J. E., Pilcher, J. R., and Hoper, S. T.: Carbon-isotope variation in sphagnum form hummock-hollow complexes: Implications for holocene climate reconstruction, Holocene, 7, 229-233, 1997.

Raghoebarsing, A. A., Smolders, A. J. P., Schmid, M. C., Rijpstra, W. I. C., Wolters-Arts, M., Derksen, J., Jetten, M. S. M., Schouten, S., Damste, J. S. S., Lamers, L. P. M., Roelofs, J. G. M., den Camp, H., and Strous, M.: Methanotrophic symbionts provide carbon for photosynthesis in peat bogs, Nature, 436, 1153-1156, doi:10.1038/nature03802, 2005.
Rice, S. K. and Giles, L.: The influence of water content and leaf anatomy on carbon isotope discrimination and photosynthesis in sphagnum, Plant Cell Environ., 19, 118-124, 1996.

Schneider, C., Glaser, M., Kilian, R., Santana, A., Butorovic, N., and Casassa, G.: Weather observations across the southern andes at 53 S, Phys. Geogr., 24, 97-119, 2003.

Segers, R. and Kengen, S. W. M.: Methane production as a function of anaerobic carbon mineralization: A process model, Soil Biol. Biochem., 30, 1107-1117, 1998.

Senesi, N., Miano, T. M., Provenzano, M. R., and Brunetti, G.: Spectroscopic and compositional comparative characterization of IHSS reference and standard fulvic and humic acids of various origin, Sci. Total Environ., 81-82, 143-156, 1989.

Skrzypek, G., Kaluzny, A., Wojtun, B., and Jedrysek, M. O.: The carbon stable isotopic composition of mosses: A record of temperature variation, Org. Geochem., 38, 1770-1781, doi:10.1016/j.orggeochem.2007.05.002, 2007.

Yu, Z., Loisel, J., Brosseau, D. P., Beilmann, D. W., and Hunt, S. J.: Global peatland dynamics since the last glacial maximum, Geophys. Res. Lett., 37, L13402, doi:10.1029/2010GL043584, 2010. 